\author{
Robert Walasek \\ University od Lodz, Faculty of Management \\ e-mail: robert.walasek@uni.lodz.pl \\ ORCID: 0000-0002-8613-8187
}

\title{
POST-TRANSACTIONAL CUSTOMER SERVICE IN A COMPANY'S COMPETITIVE APPROACH - RESULTS OF THE STUDY
}

\section{POTRANSAKCYJNA OBSEUGA KLIENTA W PODEJŚCIU KONKURENCYJNYM PRZEDSIECBIORSTWA - WYNIKI BADAŃ}

DOI: $10.15611 / \mathrm{pn} .2019 .5 .16$

JEL Classification: D12, F14, L14

Summary: The main objective of this paper is to attempt to characterize the post-transactional impact of customer service on building the competitiveness of a company. The article discusses the importance of post-transactional customer service and indicates its key impact on building long-term relationships by maximizing value for the customer. The benefits that the company achieves by using selected techniques and strategies that ensure the clear identification of clients' needs and preferences are shown. The paper also presents a discussion and results of empirical research regarding the impact of post-transaction customer service on building a company's competitiveness by creating relationships with customers. The results of the research showed that the implementation of post-transactional activities at every level of an organization's operation contributes to effective customer service and brings tangible benefits by increasing the efficiency of the supply chain, as well as affecting the creation of added value for the customer.

Keywords: post-transactional service, supply chain, competitiveness, customer, relationships.

Streszczenie: Głównym celem artykułu była próba scharakteryzowania wpływu potransakcyjnej obsługi klienta na budowanie konkurencyjności przedsiębiorstwa. W artykule omówiono znaczenie potransakcyjnej obsługi klienta i wskazano jej kluczowy wpływ na budowanie długookresowych relacji poprzez maksymalizację wartości dla klienta. Przedstawiono cele oraz korzyści, jakie osiąga przedsiębiorstwo, stosując wybrane techniki zapewniające profesjonalną identyfikację potrzeb i preferencji klientów. Zaprezentowano również wywód i przedstawiono wyniki badania empirycznego dotyczące wpływu potransakcyjnej obsługi klienta na budowanie konkurencyjności przedsiębiorstwa poprzez tworzenie relacji z klientami. Wyniki badania pokazały, że realizacja działań potransakcyjnych na każdym szczeblu funkcjonowania organizacji przyczynia się do efektywnej obsługi klienta oraz niesie wymier- 
ne korzyści poprzez zwiększenie efektywności łańcucha dostaw, jak również wpływa na tworzenie wartości dodanej dla klienta.

Słowa kluczowe: obsługa potransakcyjna, łańcuch dostaw, konkurencyjność, klient, relacje.

\section{Introduction}

Innovativeness of the economy means that the right customer service strategy (supported by IT technology) has become the main weapon in the battle for the competitive position of a company on the market. Therefore the primary goal of competing companies is to use methods and tools that are best able to serve customers and provide them with enough satisfaction to encourage them to return again in the future. The shape of relationships with clients is conditioned by skillful management. This refers not only to acquiring and retaining customers through the creation and supply of value-added, but also improving relations with other entities forming a common logistics chain.

Currently, there is no doubt that one of the most important issues in the logistics of customer service is company activities in the post-transactional area. Their overriding role is to provide customers with the ability to correctly use the products purchased, support during their operation, and in some cases, protect both the welfare and interests of the buyer. Feedback also brings added value for customer and supplier alike as a valuable source of information regarding the quality and utility features of the product, its usefulness and functionality. Thanks to this approach, enterprises are able to use ready-made solutions developed by logistics operators which relate to the emergence of the supply chain concept, in order to efficiently and effectively control inventory and optimize the path from extraction of raw materials to the end customer [Witkowski 2005]. However, the key issue for the smooth functioning of post-trade activities in the supply chain is the collaboration between all links in the enterprise chain. The lack of such cooperation or its limitation, especially with external partners, may result in leaving the supply chain and the resulting loss of competitiveness [Rutkowski 2005]. Therefore post-transactional customer service, as part of the supply chain, forces enterprises to adapt this service to specific standards expected by the customer. The tasks performed as part of these activities must be an integrated process, divided into key and complementary activities, which ultimately determine the efficiency of the supply chain [Skowron-Grabowska 2010].

The purpose of the article is to attempt to characterize the impact of posttransactional customer service on building the competitiveness of enterprises and to answer the question: is the efficiency of post-transactional customer service an important factor in creating the competitive advantage of an enterprise? The source base for the study is the available literature, secondary sources and empirical research concerning primarily the benefits obtained by selected enterprises as a result of the 
use of post-transactional customer service. Emphasis was placed on the elements of post-trade activities, and their goals and benefits that significantly affect the competitiveness of enterprises. The selection for the study sample was random and therefore the study is not a generalisation but merely a picture of the problem discussed.

\section{Post-transactional activity and enterprise competitiveness - literature review}

The change of the competition paradigm means that the creation of enterprises' competitiveness based on new products or market segmentation has become ineffective. Nowadays it is important to be able to adapt quickly and flexibly to the needs reported by customers and the ability to implement innovations that optimize operations in the supply chain and goods flow streams [Glabiszewski 2009; Zastempowski 2010]. This leads to the need for enterprises to build their competitive advantage based on additional values offered to clients, e.g. unique and difficult to replicate actions, and maintaining long-term, trust-based customer relationships [Hart 2006]. This is why the currently dominant form of economic efficiency is innovation based on connection networks between various entities operating within the same logistics chain [Grego-Planer, Liczmańska 2015]. Therefore the current, dominant form for enterprises is to create a network of links between various entities operating within the same logistics chain. Operating within the network enables the company to implement modern solutions thanks to interactive, individualized contacts with more consumers, and conducting reliable research on how they reflect on products, prices, promotions, sales methods and service quality. These activities lead not only to a competitive advantage, but also constitute the basis for building long-term partnership cooperation with selected clients based on mutual benefits (relationship value) [Otto 2006]. The effective provision of benefits to clients requires skillful management - increasingly in post-transactional activities. In general terms, such an approach increases the opportunity to achieve market advantage by creating one of the better-perceived companies on the market [Porter 1990].

At present, most companies operating in a highly dynamic global environment have begun to focus on activities aimed at emphasizing the role of an individual approach to their customers as a method to increase their satisfaction, and thus to retain them for longer [Alshourah, Alassaf, Altawalbeh 2018]. Therefore the key issues for the effective synchronization of supply and demand for enterprises are those related to comprehensive customer management in the supply chain. The strategy of ECR (Efficient Consumer Response) dominates among those strategies aimed at creating relationships with clients, as it offers not only solutions in the field of supply and demand management but also a wide range of improvements aimed at monitoring post-transactional activities such as effective response to the changing market, better customer service, and increasing efficiency in the area of service and complaints. 
The effects of applying this strategy have a long-term dimension, as actions within the ECR limit or completely eliminate mechanisms preventing the creation of additional benefits for the client. It should be noted that the more the logistics chain is focused on creating value for the client, the more effective it is [Fechner 2008]. The benefits resulting from the operation of an enterprise, especially in the posttransactional area, can be presented as the sum of the following desirable attributes: service quality, usability and functionality of the product, installation, warranty and product improvements, product tracking complaints and returns, product recalls [Harasim, Dziwulski 2018], optimization of time and costs, reliability of service and timeliness of flows in the logistics chain. Creating these benefits results from a customer service base which takes into account the level of customer expectations and preferences. This value, referred to as additional value or added value, takes into account the relationship between the knowledge about customer preferences and the possibility of creating additional value by enterprises. This is due to the fact that without value added for clients, the standing of the company in their eyes would not increase. Thus companies in their post-transactional activities which are intended to offer additional value to clients, thereby increasing the company's profitability, should be based on the Value Based Management concept. The main sources of building this value are intangible assets [Jessup 2002] i.e. goodwill (knowledge, experience, enterprise brand, customer approach, quality of service, intellectual capital, non-financial resources, hidden resources, etc.). Among these, the creation of long-term relations with clients, effective after-sales service, obtaining information regarding preferences and clients, as well as returns and complaints about products and creating databases of loyal customers are highlighted.

Undoubtedly the efficient organization of after-sales departments and the highest quality of services related to customer service brings tangible benefits to the company [Walasek 2014; Kowalczyk, Nartowska 2013]. However, continually increasing the post-transactional customer service level may have some negative consequences. Enterprises that already offer a high level of customer service as standard often decide to raise it further [Biesaga-Słomczewska, Iwińska-Knop 2013]. As a consequence, the generation of higher operating costs are elevated, which does not always translate into an increase in the level of sales, because in the majority of cases, price plays a key role in the procurement process. Therefore the determination of the benefits and losses resulting from after-sales activities should be considered individually, depending on the form of business and the product offered. Post-transactional activity costs should be determined by the cost matrix presented earlier as the proportion of unitary profit to the cost of providing a particular item. This is due to the fact that a high level of post-transactional service is often associated with the high cost of providing it. In order to limit the risk of excessive costs, the company should pay more attention to minimizing complaints regarding not only the product, but above all the quality of customer service. Customer dissatisfaction may not only be influenced by the quality of the product offered, customers can also express their dissatisfaction with such 
things as the time of delivery or quality of service. Therefore an important factor in this matter is the after-sales department staff. A qualified employee should not only be competent, but also deal with the client appropriately, treating them as a potential buyer of products in the future and as a valuable asset and source of information. An additional element used when dealing with the client should be conducting market surveys. Employees of service departments through the use of such processes, have the opportunity to obtain factual information about the level of customer satisfaction and the degree of their loyalty. The use of this knowledge allows the decision-maker to determine which actions would improve the service and product quality as well as any changes in the organization of work of individual departments, e.g. sales or production departments, which undoubtedly enhances competitiveness.

\section{Post-transactional customer service and the competitiveness of the company - research method}

The basic principle of the modern concept of customer relationship management is to adapt the product range of the company (its products and accompanying services) to the expectations of customers, which in turn leads to the effective shaping of their mutual relationships. The main criterion when targeting a particular customer base is their value and profitability for the company, taking into account the income they generate and the cost of servicing them [Ostrowska 2010]. Market dynamics and low customer loyalty means that after-sales activities are as important for the company as transaction activities. Increasing numbers of enterprises are convinced that any posttransactional activity (using various communication channels and technologically advanced tools) allows for the comprehensive and professional analysis of clients and quick responses to reported problems. Post-transactional elements also guarantee customers the proper use of products while also protecting their interests and health [Harasim, Dziwulski 2018]. In addition, this feedback is a carrier of key information on how best to adapt it to the strategic needs and preferences of customers (customer focus), all of which may bring about greater satisfaction for the customer, and this in turn will be reflected in the competitive position of the company on the market.

This is why it was important to conduct research and present the results on the use of selected post-transactional customer service tools by enterprises that may affect the creation of an enterprise's competitiveness. The main objective of the study was an attempt to define the objectives of implementation and the benefits obtained through the use of post-transactional activities that, when optimized, will contribute to the enterprise's competitiveness. The basic elements of this competitiveness were the benefits obtained by entities operating on the market as well as building a longterm relationship with customers by offering additional value. Emphasis was placed on identifying the benefits obtained by enterprises and the added value offered in the process of creating long-term relationships with customers. 
The sample selection for the study was random. On the basis of the data obtained from public administration sources available in press publications, as well as on websites, and through using specific selection criteria, a list of 126 companies was created, operating in the Łódź and Kujawsko-Pomorskie regions, which declared the use of post-trade activities in customer service. After conducting surveys and formal and substantive verification, 84 enterprises qualified for the analysis. The survey was conducted among various entities, taking into account their capital source, type of activity and period of their functioning on the market. It was addressed to middle and senior management staff responsible for post-trade activities in the company.

The survey used the questionnaire technique, the research tool of which was a research questionnaire. The survey was conducted at the turn of October and November 2018, using the questionnaire method.

Table 1. Structure of the sample in the cross-section of the surveyed features of enterprises

\begin{tabular}{|c|c|c|c|}
\hline \multicolumn{2}{|c|}{$\begin{array}{l}\text { Period of operation on the market } \\
\text { No. } 84=100 \%\end{array}$} & \multicolumn{2}{|c|}{$\begin{array}{l}\text { Business capital } \\
\text { No. } 84=100 \%\end{array}$} \\
\hline below 5 yrs & $17 \%$ & foreign & $24 \%$ \\
\hline $5-10 \mathrm{yrs}$ & $25 \%$ & Polish & $45 \%$ \\
\hline over 10 yrs & $58 \%$ & mixed & $31 \%$ \\
\hline \multicolumn{2}{|c|}{$\begin{array}{c}\text { Form of ownership of the enterprise* } \\
\text { No. } 84=100 \% \\
\end{array}$} & \multicolumn{2}{|c|}{$\begin{array}{c}\text { Number of people employed } \\
\text { No. } 84=100 \% \\
\end{array}$} \\
\hline state-owned & $2 \%$ & below 50 & $53 \%$ \\
\hline private & $94 \%$ & $50-250$ & $35 \%$ \\
\hline mixed & $4 \%$ & over 250 & $12 \%$ \\
\hline \multicolumn{4}{|c|}{ Nature of business activity No. $84=100 \%$} \\
\hline commerce & service & production & other \\
\hline $23 \%$ & $41 \%$ & $35 \%$ & $1 \%$ \\
\hline
\end{tabular}

* This variable, as a subjective characteristic, was not included in further analyses (due to the strong domination of private property).

Source: own study.

The structure of the sample concerning a cross-section of the company's characteristics are presented in Table 1.

\section{Post-transactional customer service - benefits and goals, study results}

The possibility of using modern strategies to increase the quality of services provided, including effective customer service, allows companies to promote their activities in the post-transactional area, while maximizing the added value for both the customer 
and the enterprise itself. Such activities undoubtedly contribute to the improvement of the company's profitability, and hence to the increase in its competitiveness on the market. The structure of the answers is shown in Figure 1.

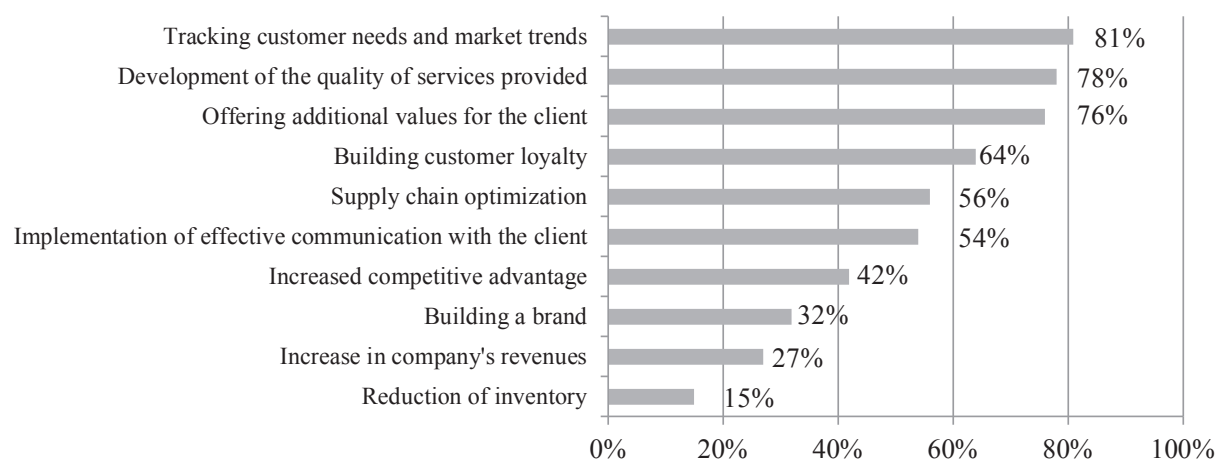

Fig. 1. Objectives of implementing Effective Customer Service Strategy (ECR)

Source: own study.

For the vast majority of surveyed enterprises (over $80 \%$ mostly production and services), the main goal when implementing and applying the ECR strategy was the ongoing monitoring of customer needs and tracking of changing market trends. In addition, over $75 \%$ of respondents declared that improving both the quality of services provided and offering additional values is also an important reason for implementing the ECR strategy. Less than $15 \%$ of the respondents - mainly production companies - felt that the implementation of the strategy would contribute to a drop in the market value of the company.

The effective use of appropriate techniques and tools in the process of improving customer relationships contributes to the improvement of activities in the posttransactional area, and at the same time increases customer loyalty to the company. Therefore the obtained benefits can be presented as the sum of the following desired attributes: service and product quality, its usability and functionality, time and cost optimization, reliability or timeliness of flows in the supply chain. The structure of the answers is shown in Figure 2.

For most of the respondents (slightly less than $90 \%$, without division into sectors), the most important benefit obtained through the implementation of the ECR strategy was an improvement in communication with the client and an increase in the quality of its service (over $80 \%$ ). Of a similar level among the declared benefits was offering value to the client. The company gained less benefit in effective inventory management or in supply chain management (less than $12 \%$ of respondents, especially services). This is due to the fact that enterprises in their activities focus primarily on increasing the efficiency of customer service, which is not always reflected in building customer loyalty or the revenue of the company. 


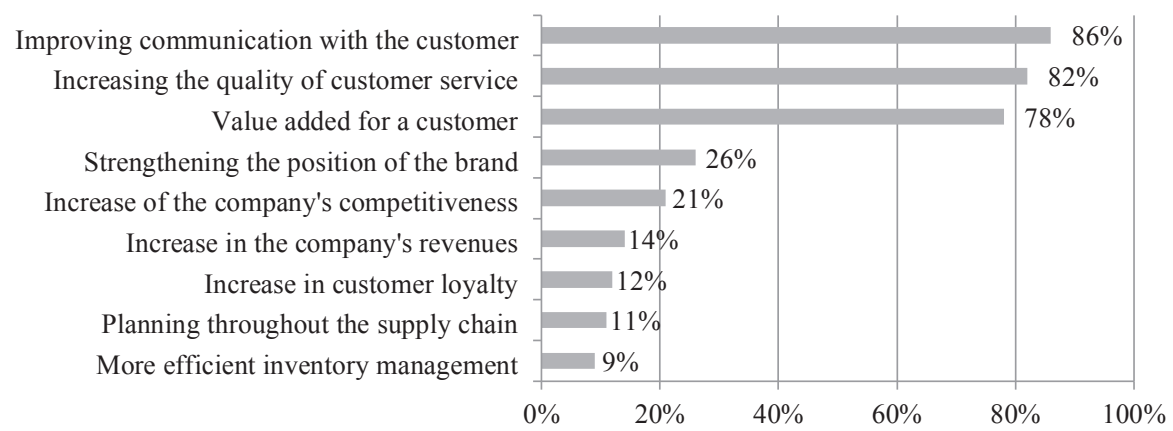

Fig. 2. Benefits for the company from implementing Effective Customer Service strategy (ECR) Source: own study.

Defining the key post-sales criteria for customer service and determining the relative validity of these criteria is an extremely important element from the point of view of the enterprises and their strategy. This allows them to focus on key areas that ensure the maximization of value for the customer, while contributing to building a competitive advantage on the market. The structure of the answers is shown in Figure 3.

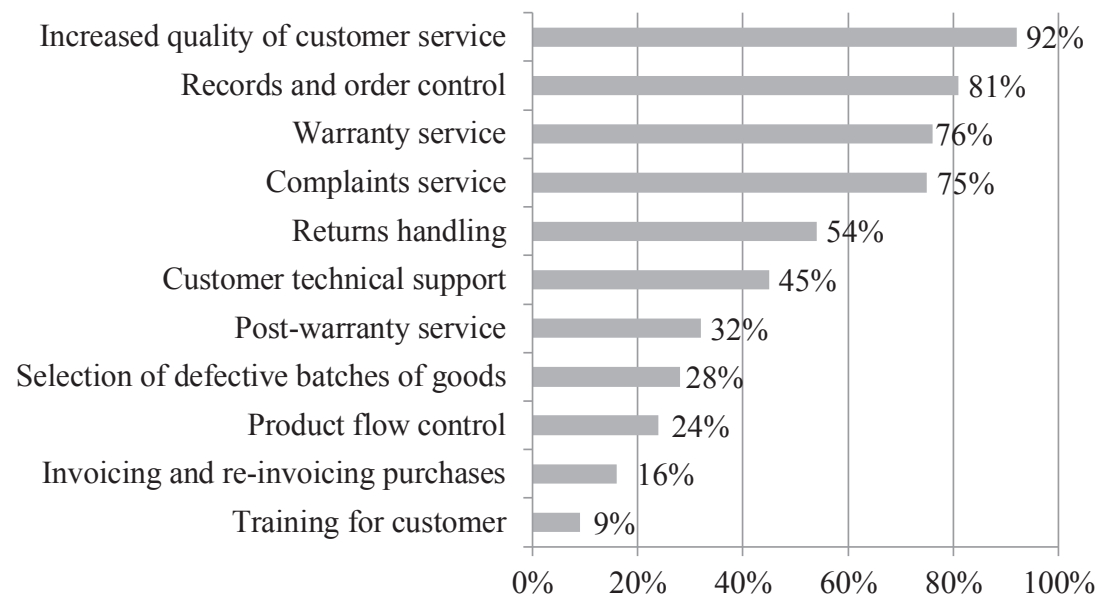

Fig. 3. Elements of after-sales activities used by enterprises

Source: own study.

We can observe that the most important element of after-sales for the majority of respondents (over 90\%), proved to be the increase in the quality of customer service. This mainly concerned companies in the service and trade industry. This state of 
affairs occurs nowhere in the era of customer orientation and the maximization of values offered in commercial processes. In addition to increasing the quality of customer service for respondents, equally important activities were: record-keeping and control of orders, handling complaints and warranty service. Such results undoubtedly demonstrate the improvement gained in activities in the area of the entire logistics chain aimed at guaranteeing clients full and professional care not only in transactional processes, but, above all, post-trade processes.

In the context of building the competitiveness of an enterprise, the implementation of post-transactional activities aimed at building long-term relationships with the customer in the entire logistics chain should affect the improvement of the functioning of the back office responsible for collecting and processing information on the current needs of the customer, including service and warranty services. The structure of the answers is shown in Figure 4.

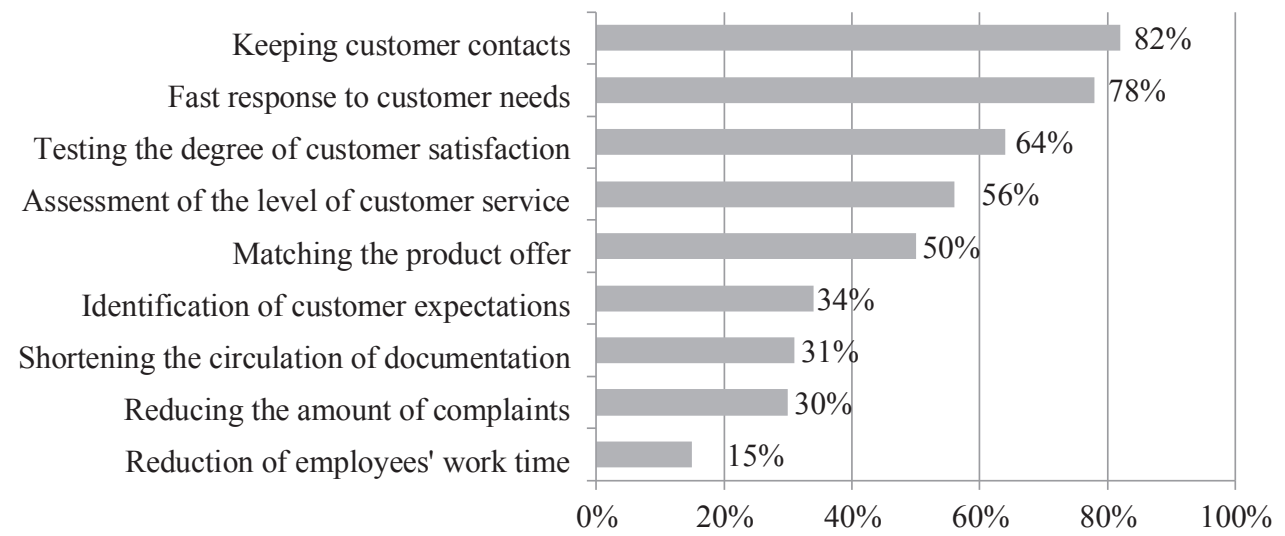

Fig. 4. The goals of implementation and application of pro-sales activities aimed at the customer Source: own study.

According to the respondents, one of the most important purposes of the application of post-transactional activities was to maintain long-term relationships with customers and offering a quick response to their needs and expectations (about $80 \%$, mostly production and trade). Such activities seem to be necessary in order to offer customers above-average value, with the goal of retaining the client base and thus strengthen the company's competitive position on the market. The least important goal for respondents was the reduction of employees' working time, irrespective of the industry (15\%). The presented graph shows that for more than half of respondents, most of the intended goals were aimed at increasing the level of customer service quality, the clients' satisfaction with contact with the company and the identification of the main expectations for the product. 
Maintaining long-term contacts with customers through the implementation of after-sales activities brings with it a number of benefits for both the enterprise and customers. Thanks to these actions, clients can be confident that they will be heard and their claims considered. This creates a sense of security for the customer, thereby strengthening their loyalty to the company. The structure of the answers is shown in Figure 5.

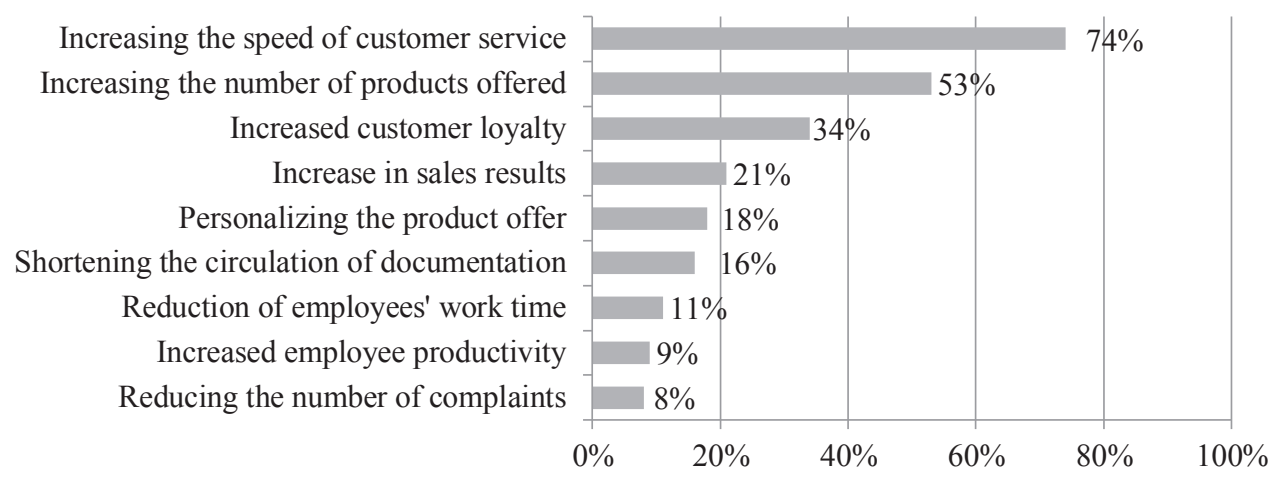

Fig. 5. Benefits of using after-sales activities

Source: own study.

The most important benefit obtained from post-trade activities turned out to be the increase in the speed of customer service at every stage of interaction with the company (74\%). This response was mainly declared by companies from the service and trade industry. For more than half of the respondents (mainly production companies), this was an increase in the number of products offered through the use of up-selling or cross-selling, whereas fewer than $10 \%$ of respondents said that they were able to reduce the number of complaints and increase the efficiency of employees. Undoubtedly the level of the achieved benefits may indicate that activities in the post-trade area significantly contribute to improving customer relationships, thanks to which enterprises can effectively build their competitive position on a volatile market.

\section{Conclusions}

Nowadays, to gain and maintain a strong market position, especially in the services sector, it is not enough to satisfy consumer needs regarding the level of quality and price of the purchased product. The identity of the client is also extremely important for the company after the transaction. Post-transactional activities related to handling complaints do not translate directly into revenue growth but do constitute a basic element of creating trust in the company, which in turn leads to building long-term 
partnerships. As research shows, well-coordinated post-trade activities translate into offering above-average benefits for the customer. Considering the benefits obtained by companies and clients, the implementation of post-transactional activities at every level of an organization's operations contributes to an effective customer service and increases the efficiency of the supply chain, and creates added value for the customer. These include: the greater availability and usability of products, reduced amount of damage, improved service and customer service, better quality products, the elimination of shortages of goods purchased, the greater prestige from owning the brand and more accessible information about the products. In addition, the benefits are also felt on the side of enterprises. These include, among others, increasing the speed of customer service, reducing product recalls, increasing the flexibility of the entire supply chain, increasing customer loyalty and the better planning of production and distribution. Both literature studies and research confirm the very large increase in the expectations and requirements of customers regarding the posttransactional activity of enterprises. Customer satisfaction with the complaint or repair processes is a derivative of high efficiency in the organization of logistics processes responsible for post-transactional service. These actions not only cause customers to become more loyal to the company, but also determine the scale of its market competitiveness. It seems necessary to continue research and observation of post-transactional activities of enterprises in the context of the rapidly changing needs and preferences of customers. A flexible and quick response to changes in the area of after-sales activities can contribute to increased company competitiveness.

\section{Bibliography}

Alshourah S., Alassaf H., Altawalbeh M., 2018, Roles of Top Management and Customer Orientation in Enhancing the Performance of Customer Relationship Management (CRM) in the Hotel Industry, Zarqa University, Jordan, p. 236.

Biesaga-Słomczewska E.J., Iwińska-Knop K., 2013, Logistyczna obstuga klienta w świetle badań, Logistyka, no. 2, p. 118.

Fechner I., 2008, Nowe wyzwania - nowe rozwiazania, Materiały konferencyjne z Polskiego Kongresu Logistycznego, Instytut Logistyki i Magazynowania, Poznań, pp. 76-77.

Glabiszewski W., 2009, Innowacje technologiczne i ich źródta w małych i średnich przedsiębiorstwach regionu kujawsko-pomorskiego, Zeszyty Naukowe Uniwersytetu Szczecińskiego, Ekonomiczne Problemy Usług, no. 34, p. 182.

Grego-Planer D., Liczmańska K., 2015, Innowacje sektora MŚP w województwie kujawsko-pomorskim, Studia Ekonomiczne, Zeszyty Naukowe Uniwersytetu Ekonomicznego w Katowicach, no. 261, p. 167.

Harasim W., Dziwulski J., 2018, Logistyczna obshuga klienta i jej znaczenie z perspektywy strategii organizacji, [in:] Harasim W. (ed.), Determinanty nowoczesnego zarządzania, Wyższa Szkoła Promocji, Mediów i Show Businessu, Warszawa.

Hart M.L., 2006, Customer relationship management: are software applications aligned with business objectives? South African Business Manager, vol. 37(2), pp. 17-32. 
Jessup H.A., 2002, Intellectual capital: measuring knowledge assets, Knowledge Management Review, no. 5 .

Kowalczyk M., Nartowska A., 2013, Zarzadzanie relacjami z klientem (CRM) jako element infrastruktury logistycznej, Logistyka, no. 5, p. 104.

Ostrowska I., 2010, Model ksztaltowania lojalności konsumentów w stosunku do marki, Wydawnictwo Uniwersytetu Szczecińskiego, Szczecin, p. 130.

Otto J., 2006, Relacje z klientami a wartość przedsiębiorstwa, [in:] Czubała A. (ed.), Marketingowe strategie budowania wartości przedsiębiorstwa, Akademia Ekonomiczna w Krakowie, Kraków, pp. 325-331.

Porter E.M., 1990, The Competitive Advantage of Nations, Macmillan Press Ltd., p. 73.

Rutkowski K., 2005, Logistyka dystrybucji. Specyfika. Tendencje rozwojowe. Dobre praktyki, Oficyna Wydawnicza SGH, Warszawa, p. 76.

Skowron-Grabowska B., 2010, Centra logistyczne w tańcuchach dostaw, PWE, Warszawa, p. 55.

Walasek R., 2014, Kultura organizacji w zarządzaniu relacjami z klientem, [in:] Juźwicka A., Szymańska K., Walecka A. (eds.), Nowe spojrzenie na kulturę organizacyjna, Politechnika Łódzka, Łódź, s. 116 .

Witkowski J., 2005, Organizacje sieciowe, sieci strategiczne i łańcuchy dostaw - próba systematyzacji pojęć, Prace Naukowe Akademii Ekonomicznej we Wrocławiu, no. 1078, p. 183.

Zastempowski M., 2010, Uwarunkowania budowy potencjału innowacyjnego polskich matych i średnich przedsiębiorstw, Wydawnictwo Naukowe UMK, Toruń, p. 56. 